This item was submitted to Loughborough's Research Repository by the author.

Items in Figshare are protected by copyright, with all rights reserved, unless otherwise indicated.

\title{
Organizing for individuation: alternative organizing, politics and new identities
}

PLEASE CITE THE PUBLISHED VERSION

http://dx.doi.org/10.1177/0170840616641983

\section{PUBLISHER}

(c) The Authors. Published by SAGE Publications

\section{VERSION}

AM (Accepted Manuscript)

\section{PUBLISHER STATEMENT}

This work is made available according to the conditions of the Creative Commons Attribution-NonCommercialNoDerivatives 4.0 International (CC BY-NC-ND 4.0) licence. Full details of this licence are available at: https://creativecommons.org/licenses/by-nc-nd/4.0/

\section{LICENCE}

CC BY-NC-ND 4.0

\section{REPOSITORY RECORD}

Reedy, Patrick, Daniel King, and Christine Coupland. 2016. "Organizing for Individuation: Alternative Organizing, Politics and New Identities”. Loughborough University. https://hdl.handle.net/2134/20773. 


\title{
Organizing for individuation: alternative organizing, politics and new identities
}

\author{
Abstract \\ Patrick Reedy, University of Hull p.reedy@hull.ac.uk \\ Daniel King, Nottingham Trent University \\ Christine Coupland, Loughborough University
}

Accepted for publication Organization Studies March 2016

Organization theorists have predominantly studied identity and organizing within the managed work organization. This frames organization as a structure within which identity work occurs, often as a means of managerial control. In our paper our contribution is to develop the concept of individuation pursued through prefigurative practices within alternative organizing to reframe this relation. We combine recent scholarship on alternative organizations and new social movements to provide a theoretical grounding for an ethnographic study of the prefigurative organizing practices and related identity work of an alternative group in a UK city. We argue that in such groups, identity, organizing and politics become a purposeful set of integrated processes aimed at the creation of new forms of life in the here and now, thus organizing $i$ s politics $i$ identity. Our study presents a number of challenges and possibilities to scholars of organization, enabling them to extend their understanding of organization and identity in the contemporary world.

\section{Vignette 1: An introduction to the Midtown alternative scene}


On a cold and windswept evening in March we gathered at a small organic wholefood co-operative shop amongst insalubrious takeaways in one of the scruffier parts of Midtown. As we arrived, greetings were called, mugs of tea made, and soon 25 people were crammed into the room. Although a public meeting, many participants already knew each other. The 'formal' part of the evening began when those who had initiated the meeting, including Author 2, explained that they wanted to bring likeminded people together to forge closer ties and foster joint action. Each of us explained who we were, why we were there, and what group we belonged to (if any). This was recorded on flip charts and minuted for later distribution. Although membership overlapped considerably, there were around twenty groups including environmental organizations, radical political parties, local activist groups, alternative food and craft retailing, arts and music groups; many belonged to several of these groups simultaneously.

Most were young (between 25 and 40) and their appearance often reflected alternative youth sub-cultural norms - a 'hippyish' look for women, dreadlocks and goatee beards for men, although older attendees wore jumpers, t-shirts and jeans. Everyone seemed happy at a slightly ironic self-description of 'alternative', though deciding what this meant became a major debate. All agreed that it implied non-commercial and non-consumerist values with social/political/ethical aims and consensual democratic organizing. Concerns emerged about how difficult this was in practice, often due to lack of money or time.

Despite the need for money, some argued that paid work or grants undermined autonomy and self-sufficiency. Whilst a few had full time jobs (usually in the public sector or with charities), many kept paid work to the minimum, desiring to live entirely 'off-grid'. Most wanted to engage with 'the community' to further political 
aims and there was a consensus that a shared social centre would be a good way to do this. The evening concluded with many of us going to a nearby pub to continue our discussion.

\section{Introduction}

Our opening vignette sets the scene for our study of the Midtown Alternative Consensus (MAC) where we explored a significant and neglected relationship between organizing and the self. 'Organizations rather than organization' (Ahrne \& Brunsson, 2011, p.84), and particularly the formal work organization, predominate within organization studies (OS), largely located in business schools (Parker, 2002).Organization is assumed to occur in structured spaces which employees may enter and exit but rarely have opportunities to fundamentally alter. Our contribution is to extend organization theory beyond this limited view by developing the concept of individuation pursued through prefigurative practices within alternative organizing. To do this we contrast individuation with individualization (Beck \& Beck-Gernsheim, 2002) which, as we argue below, is assumed to underpin identity projects in more traditional organizations. We define individuation as collective organizing practices undertaken in pursuit of autonomous selves. In our study, individuation was pursued through prefigurative practices which can be defined as a form of politics in which desired outcomes are created in the here and now rather than projected into the future.

Our primary research question is whether, and how, individuation projects pursued through prefigurative practices enable more autonomous selves? Our study reveals how prefigurative practices involved a complex interaction of conviviality, mutual aid, political activism, deliberative consensual decision-making, self-provisioning, artistic endeavour and subcultural differentiation. We theorise under what circumstances the desire for unimpeded 
freedom and the desire for communal belonging and democratic organizing might be successfully negotiated.

Our opening vignette introduces our ethnographic study of the MAC, a loose confederation of alternative groups that provided a vivid example of the use of prefigurative politics as individuation. In seeking to learn from the everyday lives of those who pursue 'the art of not being governed' (Springer, 2012, p.1617), we observed a range of collective practices aimed at the satisfying of material, existential and social needs and at changing wider society. We argue that the practices of the MAC are typical of a growing constellation of social movements (Maeckelbergh, 2011b; McDonald, 2006). Castells, Caraça, and Cardoso (2012) argue that these practices represent a significant societal shift, involving a growing number of individuals, particularly the young within new social movements. Hardt and Negri (2000; 2004) argue that the emerging predominance of immaterial labour will provide a further impetus to a shift away from traditional work organizations and towards the self-organizing networks typical of groups such as the MAC.

New social movements and their alternative organizing practices have received increasing attention within OS (Fournier, 2006; Parker, Cheney, Fournier, \& Land, 2014; Parker, Fournier, \& Reedy, 2007; Reedy \& Learmonth, 2009). Engagement with such movements has come to be seen as an important part of critical organization studies (Spicer \& Böhm, 2007; Willmott, 2008; Zald \& Lounsbury, 2010). Despite this attention, the everyday organizing practices and lives of movement members remain relatively unexplored. However we propose that it is only in theorising these practices that distinctive individuation projects based upon prefigurative politics may be understood. In contrast, the work of activistethnographers within social movement theory (see Barnard, 2011; Chatterton \& Pickerill, 2010; Fominaya, 2010; Maeckelbergh, 2012, for examples) has explored everyday organizing practices but tends to do so with evident proselytising intentions and without 
sufficient critical attention to the difficulties and contradictions of sustaining them. We therefore offer a distinctive contribution by combining our own engaged ethnography of prefigurative practices with the critical sensibilities of organizational scholarship.

We continue by developing our theoretical position, contrasting the concept of individualization with that of individuation, specifically individuation pursued through prefigurative practices, identifying questions and problems that we address in our empirical analysis. We then explain our methodological approach, before presenting our account of the struggles, achievements and tensions of prefigurative individuation within the MAC. Finally, we discuss a number of challenges to, and possibilities for, OS arising from our study, particularly the significance of individuation for our understanding of the relation between identity and organizing.

\section{Individualization and Individuation}

'The individualization thesis' (Araujo \& Martuccelli, 2014; Atkinson, 2008), influential within sociology, theorises selfhood in the contemporary world. Beck (Beck \& BeckGernsheim, 2002), Giddens (1991) and Bauman (2000) are considered by Elliott (2014) to be its most significant proponents. Honneth (2004) observes that all three draw on Weber's argument that capitalism eradicates traditional ascriptive forms of collective identity, promising greater individual autonomy as people become able to choose their occupations and affiliations. For Beck, individualization extends this trend to the requirement that 'individuals must produce, stage and cobble together their biographies themselves' (Beck, 1997, p.95). For Giddens (1991), individualization relies on reflexively selecting from amongst lifestyle options. Bauman (2000) stresses the fluid, precarious, de-institutionalized and globalised nature of individualization. 
Individualization's potential for autonomy is seen as compromised by forces inherent within capitalist societies. Elliott, for example, notes the 'sheer amount of emotional and interpersonal work demanded for self-reorganization, self-construction and self-reassembly' (2014, pp.163-164). Bauman writes of the anxiety resulting from the lack of stable foundations for identity and of the risk of becoming trapped in the stigmatized 'vagabond' identities (Atkinson, 2008; Bauman, 2000) associated with the underclass. Sennett (1998) chronicles the difficulty of maintaining a coherent life narrative in the face of the decline in secure work. Putnam (2000) laments the decline of the social capital and communal belonging in an individualized world. Choice is argued to be more apparent than real. As Araujo and Martuccelli note, 'in no society do individual actors invent subject ideals. These ideals are offered and put at their disposal' (2014, p.27). Stiegler (2006), amongst others (Atkinson, 2008; Elliott, 2014; Honneth, 2004; Read, 2011), argues that these ideals rely on representations of successful lives sold to us by the media, the market and the workplace.

The individualization thesis has influenced how OS understands identity: i.e. a precarious biographical project vulnerable to capture by ready-made identities and so subject to managerial control (Collinson, 2003; Whittle, Mueller, \& Mangan, 2009). Work organizations are seen as arenas where individuals embrace, modify or resist such identities (Alvesson \& Willmott, 2002; Beech, 2008) and are often seen as sites of determination rather than autonomy (Barratt, 2003; du Gay, 1996; Hodgson, 2000; Rose, 2000). Personal success, consumption, dynamism, entrepreneurship and constant reinvention make up 'stereotypical images of a competitive entrepreneurial 'self' (Ybema, Keenoy, et al., 2009, p.310), the dominant identity promoted within work organizations (du Gay, 2000; du Gay, Salaman, \& Rees, 1996; McCabe, 2008). There is a large body of work on managerial attempts to control employees through the regulation of identity (Alvesson \& Willmott, 2002; Mumby, 2005). 
Costas and Fleming's study of managerial demands that employees 'be themselves' (2009, p.240) illustrates how individualization is utilised for management control. In our study, we consider the possibility of alternatives to this regulated individualization. Can autonomy be recovered through a re-appropriation of organization? To begin to answer this question, we now turn to the concept of individuation, seen by Boucher and Maslach (2009) as the antithesis of individualization.

Individuation is used within social theory to indicate the processes by which one's self becomes differentiated from others (Atkinson, 2010). The term is often used in a positive sense to indicate cooperative 'agentic individualism' (Araujo \& Martuccelli, 2014, p.24) contrasted with the asocial individualized person concerned only with self-gratification (Rozuel \& Kakabadse, 2010). Beck and Beck-Gernsheim (2002) use individuation in this sense. The individuated self has the capacity to pursue their own projects in collaboration with others. The individualized self appears to be behaving agentically whilst actually conforming to external social influences.

For us, individuation also has an explicitly political dimension. Marx (1873/1973) argued that individuation requires active engagement in organization as a collective political project (Read, 2011). Castells suggests an explicitly political dimension to individuation in his work on the construction of communicative autonomy via social media (Fenton \& Barassi, 2011) and also, in his studies of post-financial crash political movements such as Occupy (Castells, 2012; Castells et al., 2012). Stiegler (2006) has proposed that speaking out enables the individual to establish his or her singularity through self-expression (Fenton \& Barassi, 2011). Individuation requires coming together to self-consciously confront the options for selfhood and to challenge prevailing social norms. 
We propose that individuation may provide a way of reconsidering the relation between identity and organization by moving beyond 'an individualized narrative of career that cultivates constant entrepreneurial activity and associated forms of self-discipline' (Alvesson, Ashcraft, \& Thomas, 2008, p.9). In particular we turn to a form of individuation based upon the prefigurative practices within some new social movements (see Castells et al., 2012; Kokkinidis, 2014; Sutherland, Land, \& Böhm, 2013, for examples). These writers argue that, as new generations find themselves excluded from the work-based identities associated with formal employment, they are turning to a 'do-it-yourself' approach, utilising alternative forms of organization (Imas \& Weston, 2012; Morris, 2012). Thus growing numbers engage in convivial, cultural, mutual aid, activist and self-provisioning practices that prefigure the emergence of new social forms (Maeckelbergh, 2011a).

\section{Prefigurative Organizing in New Social Movements}

In an overview of alternative organizing, Parker, Cheney, Fournier and Land (2014) trace the emergence of new social, political, and co-operative movements (see also Böhm, Dinerstein, $\&$ Spicer, 2010, for further examples) characterised by prefigurative practices. Prefiguration may be understood as a politics of immanence in that, as Gautney (2009) has observed, rather than projecting the desired outcomes of political action into the future, prefiguration creates them in the here and now. The alter-globalization movement, as characterised by Maeckelbergh $(2009,2011 \mathrm{a})$ amongst others, are seen to embody such prefiguration in their values, social relations, organizational methods and forms of life. Prefiguration collapses the temporal distinction between ends and means (Kokkinidis, 2011) as 'everyday practices are used as building blocks to construct a hoped-for future in the present' (Chatterton \& Pickerill, 2010: 476). Fominaya (2010) argues that commitment to prefigurative practices is seen as being more significant and attractive to activists than commitment to set ideological positions or a future post-revolutionary utopia. 
As Parker (2012) has argued, hierarchy and leadership, as understood in management theory, are rejected by these movements. Both are seen as entailing domination and oppression (Maeckelbergh, 2009). Rather, organizing takes place via fluid networks (Castells, 2012; Featherstone, 2008), that potentially facilitate organizing without hierarchy or central control. Following Freeman's warnings of the eponymous 'tyranny of structurelessness' (2013) there has been much discussion of the persistence of power and dominance in what purport to be radically democratic, inclusive and egalitarian forms of organizing. Diefenbach and Sillince, for example, note the re-emergence of domination via persistent 'structures of communication' (2011, p.1529) and differential communicative skills. Studies of worker cooperatives suggest the near inevitability of degradation (Heras-Saizarbitoria, 2014), i.e. the tendency for initially democratic organizations to revert to a hierarchical and managerial model. Some SMT theorists suggest that the conscious use of self-critical discussion may counter these pervasive tendencies (Chatterton \& Pickerill, 2010; Maeckelbergh, 2012).

In order to arbitrate between these contrasting viewpoints, we need to examine how prefiguration plays out in the everyday lives of those engaged in alternative organizations. However, in OS, such studies are unusual and social movements are mostly, as Soule (2012) argues, considered through the lens of managerial concerns. However, activist-ethnographers from within SMT, particularly participative action researchers within social geography (Gibson-Graham, 2006; Gibson-Graham, Cameron, \& Healey, 2013) have studied these practices and provide us with some useful insights into prefigurative organizing.

SMT suggests that the preferred radically democratic, loosely coupled networks of alternative organizing are held together by 'personal identity relationships' (Pickard, 2006, p.320) relying on 'interpersonal relations of trust.' (Haug, 2013, p.712). Such networks enable groups to coalesce to organize political campaigns, or events such as festivals but do not require hierarchical authority for coordination. They enable a sense of collective belonging as 
well as providing options for individuation. However, they are also prone to fragmentation as a result of disagreement or shifts in affinities (Chatterton \& Pickerill, 2010; McDonald, 2006; Melucci, 1989). Day to day organization tends to be intensely local (because it relies on sociality to maintain bonds) but wider engagement is also common via new communication technologies (Castells, 2012; Pickard, 2006; Wall, 2007).

To avoid hierarchy, fully participative consensus decision-making, sometimes referred to as 'horizontal democracy’ (Maeckelbergh, 2012, p.207) is widely adopted. How decisions are made is as important as the decisions themselves and meetings are seen as one way of constructing the desired shared 'common' of cooperation and affinity in the here and now (Murray, 2010; Owen, 2008). Prefigurative organizing is seen as a way of constructing a positive sense of autonomous selfhood affirmed within a community of shared values (McDonald, 2006). Deliberative practices enable a collective 'struggle over dominant discourses' (Bieler, 2011, p.167) of identity as participants are encouraged to speak out, assert themselves and challenge others during assemblies. This prefigurative activism is thus described as 'personalism' by some (Clemens \& Minkoff, 2004; McAdam, McCarthy, \& Zald, 1996) and is a key aspect of individuation. Competitive individualization is rejected in favour of communal values such as reciprocity, equality and cooperation.

Shared lifestyle and conviviality are considered central to collective identity by some SMT theorists. Saunders (2008), for example, argues that common subcultural practices derive from 60's counter-cultural norms. McDonald (2006) and (Maeckelbergh, 2011b) see the festival culture as the medium by which these norms are passed on to new generations. We would argue that these subcultural norms are apparent in groups such as the MAC but that, alone, they are more characteristic of individualization than of individuation. It is their combination with political purpose that constitutes them as prefigurative practice. Thus Fominaya (2010) observes that, rather than being hedonistic, activist lives are frequently 
characterised by the sacrifice of time, energy and income sometimes resulting in frustration, hardship, bodily danger and economic insecurity. Movement members' lifestyles reflect a commitment to low-consumption, non-commodified lives, in opposition to the norms of capitalism (Chatterton, 2010). The bonds of trust established by shared sacrifices and hardships run deeper than a more casual sociality and oppositional political identity is identified as an important component of selfhood within these movements (Chatterton \& Pickerill, 2010).

All organizing requires that participants come together to make decisions and maintain relationships. The term 'assembly' (Fominaya, 2010, p.380) is used to denote a prefigurative expression of this. Assembly is a 'coming together of various entities into a loose aggregate...to temporarily establish order within a given social setting' (Davies, 2012, p.274), contrasting it with the more permanent, less negotiable, structures of traditional organizations. Assemblies are created and maintained by participants 'through shared leadership, organization, ideologies and rituals' (Fominaya, 2010, p.380). The skill and commitment that members bring to assembly largely determines whether a sense of collective identity is achieved (Maeckelbergh, 2012; McDonald, 2006). Chatterton and Pickerill argue that assemblies produce 'nurturing capabilities, in effect developing resilience, empathy and coping skills that build community as a bedrock for more oppositional identities and actions' (2010, p.481). Likewise Davies notes that assembly fosters 'dense inter-organizational networking, by actors linked by solidarities and shared identities that precede and survive any specific coalitions and campaigns' (2012, p.274). Assembly takes place in and refigures physical and virtual spaces for individuation projects. Its norms and deliberative methods are prefigurative, foreshadowing the creation of new models of organizing.

To summarise, our characterisation of prefigurative individuation may be seen as relying on the maintenance of social bonds through conviviality, reciprocity, and political activism. The 
ideal of 'do-it-yourself' living (Moore \& Roberts, 2009) prefigures the non-commodified society to come and seeks to avoid the authoritarianism of the workplace. Shared sub-cultural lifestyles, reflected in dress, festival going, food, music and art, reinforce these bonds and provide opportunities for creative self-expression. The assembly provides a negotiable space in which horizontal democracy is practised and activism organized. In the next part of the paper we analyse the everyday activities of one group of alternative organizers who use these practices. We begin to answer our initial question as to the extent that such practices facilitated individuation as opposed to individualization. Do we see new autonomous forms of identity, or the making of a virtue out of necessity caused by economic exclusion from more conventional lives? Do the control, power, and domination they seek to escape simply re-assert itself in a different form or are its negative effects countered through the conscious challenging of hierarchy and authority in assembly? Next we explain how we undertook our study before turning to these questions.

\section{Methodology}

Ethnography, 'based on close contact with the everyday life of the studied society or group over a fairly long period of time' (Alvesson \& Skoldberg, 2000, p.45), suggested itself to us as an appropriate method. We wished to generate an empathetic understanding in readers unlikely to be familiar with groups like the MAC (Brunwick \& Coghlan, 2007; Cunliffe, 2010; Watson, 2012) and to challenge dominant understandings through contact with the other (see Barnard, 2011; Glass, 2012; Morris, 2012; Rimmer, 2010, for example), enabling marginalised voices to be heard (Imas, Wilson, \& Weston, 2012), and remedying a 'apolitical reading of organizing' (Ybema, Yanow, Vels, \& Kamsteeg, 2009, p.7). 
This approach was greatly helped by one of the authors (Author 2) already being an active participant in the setting for a number of years previous to the study and who remains so at the time of writing. Author 2 has lived for two decades in the city where our study took place and has participated in the group's activities for half that time, including helping organize meetings and events. This enabled a truly 'insider' perspective (Brunwick \& Coghlan, 2007; Karra \& Phillips, 2008) over an extended time frame. Following Alvesson (2003), we characterise our approach as 'self-ethnography', where authors are reflexive interpretive instruments of the research making use of their own experiences (Humphreys, Brown, \& Hatch, 2003) but not the chief objects of study.

In order to gain sufficient critical distance from insider assumptions (Alvesson, 2003) we devised a 'team approach to ethnography' (Fortune \& Mair, 2011, p.458). Author 1 engaged intensively with the setting during a critical six month period as more observer than participant although his own political convictions make him sympathetic to the MAC's aims. He attended a series of planning meetings, took part in post-meeting social events, engaged in informal conversation and interviewed key members of the group. He was able to take notes and ask questions that were difficult for Author 2, often fully engaged in helping run the events described. Both authors engaged in constant discussion, enabling the surfacing of tacit understandings and knowledge. Author 3 was not actively engaged in the setting or involved in political activism but was highly knowledgeable regarding identity projects in conventional organizing. We were thus able to evaluate the data from an expert outsider perspective enabling a further 'de-naturalisation' and challenging of the interpretations of the other authors. In line with the practices of the group we studied, we sought as authors to arrive at a consensus regarding our interpretations. Where disagreement persisted, and where significant for our arguments, we include our different interpretations in our discussion. 
Our study took place in a small manufacturing city in the UK, 'Midtown'. The most intensive phase of our study took place between March and August 2009 when the self-described 'Midtown Alternative Consensus' (MAC) were forging closer ties through developing a 'social space', defined by Chatterton and Pickerill as 'place projects that can be squatted, rented or cooperatively owned [including] elements such as book shops, affordable cafes and bars, food cooperatives, free shops, spaces for meetings, cultural/political events and educational activities' (2010, p.479). This project brought together a cross-section of alternative groups in a series of meetings and events, culminating in the holding of three festivals in 2009 and 2010. It should be stressed that the MAC is not an 'organization' in the usual sense; their website aptly describes them as 'a loose collective connecting and celebrating alternative organizations, people and events in, and around, Midtown'.

It is consequently difficult to categorise MAC members. Appearance, age, gender, and class all varied widely and we are reluctant to specify a MAC 'type'. People also participated in very different ways, from occasional attenders at events through to a complete commitment to alternative lifestyles and 'off-grid' living. These caveats aside, most MAC members were between 25 and 40. We observed no significant gender imbalance, either numerically or in terms of participation. Sexual orientation was not a focus of our study or very apparent given that in the MAC it was considered unremarkable. Class is likewise difficult to generalise about but there was a preponderance of what we would describe as 'lower-middle/upperworking class' members. I.e. most MAC members were reasonably well-educated (many were graduates) with parents in skilled/lower ranking professional occupations and had neither experienced severe poverty nor secure affluence. Additionally, participation in the MAC entailed an explicitly do-it-yourself, anti-consumerist and egalitarian ethic and lifestyle, obscuring visible indicators of class. 
We used a number of data collection methods including observing, informal conversation, interviews, questions at meetings, participation at events and the analysis of various documents. Over the central period, authors 1 and 2 attended ten public meetings, although Author 2 has attended meetings and events over ten years. Notes were made, mostly by Author 1, during meetings or as soon as possible afterwards. Locations and spaces central to the life of participants provided opportunities for observation of place and self-presentation. We read and summarised emails, web pages, social networking sites and electronic messages. Finally, Author 1 conducted six in-depth life history interviews with key participants, yielding more detailed biographical accounts of MAC members. Author 2 conducted a further two interviews in order to clarify certain aspects of the MAC's organizing practices.

Data was analysed through constant re-reading and discussion between all three authors to identify significant themes. We encountered the usual problem of presenting rich ethnographic description within the confines of a journal paper (Van Manaan, 2010). Our solution was to use vignettes supplemented by other data excerpts. Vignettes are a wellestablished way of communicating the context and 'feel' of ethnographic data (Barter \& Renold, 2000), particularly self-ethnographic data (Humphreys, 2005). In the following account we have paid particular attention to how individuation was pursued through prefigurative practices. We use the key elements of prefigurative practices derived from our theoretical analysis above to structure our data and draw attention to the issues of power and domination, and the various contradictions and tensions that characterise the lives of the MAC. At the start of the paper we set the scene of our study by describing the first meeting of the MAC attended by both Author 1 and 2 (vignette 1). We continue by analysing this vignette to reveal significant aspects of the everyday practices of the MAC. 


\section{Organizing for Individuation in the MAC}

We structure the following discussion on themes that emerged in our theoretical analysis as typical of similar social movement groupings elsewhere (horizontal democracy, conviviality, mutual aid, activism, self-provisioning, cultural production and sub-cultural identification). Here, we trace how these combine to produce distinctive alternative identities through the MAC's organizational processes and how they reveal the tensions, contradictions and vulnerabilities that arise from such processes.

The meetings we attended illustrated many of the prefigurative practices identified above including consensus decision-making (see also Maeckelbergh, 2012). Peter, one of the facilitators of the meetings, described himself as 'heavily inspired by the Zapatistas' use of horizontal democracy (Interview by Author 2) and the MAC's Google website describes them as 'a non-hierarchical group which encourages participation by anyone who would like to be involved'.

The first three meetings we attended were described by one MAC member in the MAC's 'MacZine', ('a platform for anyone who wants to use it') as follows:

In order to introduce the social centre idea to the wider public as well as raising our own awareness of alternatives in the city whilst also cultivating our organization and facilitation skills, we would organize an event. We engaged in a visioning exercise before expressing our different ideas regarding what we would like to see happen...It was agreed that open democratic meetings would be held every two weeks

\section{Excerpt from 2009 copy of MacZine}

Consensus was initially constructed through agreeing shared values: 
Peace, love, freedom, autonomy, justice, solidarity, creativity, entertainment, process and democracy' [with the aim of producing an] 'autonomous, inclusive and democratic group.

\section{Quotes taken from the MAC website in July 2009}

These rather generic values accommodated a diverse range of individuation projects based on alternative lifestyles and activism. This range was reflected in the affiliations reported in our first meeting. We noted:

\begin{tabular}{|c|c|}
\hline Five national/international political organizations & $\begin{array}{l}\text { Transition Towns } \\
\text { Sustrans } \\
\text { Unite Against Fascism (UAF) } \\
\text { Freeman Conference } \\
\text { Socialist Workers' Party (SWP) }\end{array}$ \\
\hline Five local activist organizations & $\begin{array}{l}\text { Two anarchist groups organizing arts events and } \\
\text { consciousness raising discussion groups based on } \\
\text { 'Open Space' principles. } \\
\text { An on-line alternative events/political magazine } \\
\text { collective } \\
\text { A climate change group } \\
\text { An alternative transport group }\end{array}$ \\
\hline Three alternative businesses/producers & $\begin{array}{l}\text { An organic wholefood retail cooperative } \\
\text { A group who occupied land and grew their own } \\
\text { food } \\
\text { An arts and crafts producer-retailer funded by the } \\
\text { Princes Trust } \\
\text { A second-hand goods exchange linked to the }\end{array}$ \\
\hline
\end{tabular}




\begin{tabular}{|l|l|}
\hline Four arts groups - collectives who worked & AETS (local exchange and trading scheme) \\
together to produce art and perform & A musical collective that put on weekly music \\
nights & A dance group \\
& An art student collective that jointly organized \\
& exhibition spaces \\
\hline
\end{tabular}

Taken from fieldnotes made by Authors $1 \& 2$ compiled from flipcharts written at the first meeting of the MAC.

Meetings attempted to achieve collective aims without compromising the autonomy or happiness of participants. As Peter said 'I believe that as an individual, you should try and be happy and I don't want to be kind of making too many sacrifices for some kind of destination that I'm working towards' (Interview with Author 1) but preserving autonomy whilst achieving joint aims often generated tensions, particularly trying to maintain the prefigurative ideal of non-hierarchy. Leadership in the assembly is seen as ideally arising from the deliberation process itself, based on persuasive or skilled contributions and so not accruing to particular individuals or to formally defined roles. However, in practice, some MAC members possessed a higher level of skill or commitment than others and tended to lead MAC meetings. We thus observed the paradox of customary leaders who were opposed to the notion of leadership. Peter, a particularly influential MAC member, attempted to reconcile this tension by reinterpreting leadership as being 'an example to others, to try and lead by example...rather than trying to just preach and coerce people to do things' (Interview with Peter by Author 1). The MAC collectively resisted leadership becoming the preserve of a few by devoting a great deal of time to discussing how decisions were, or should be, made (see vignettes 6 and 7 below for examples). Author 1 felt that this was often at the expense of 
actually taking decisions. However, Author 2 interpreted such discussion as central to the prefigurative ideals of the MAC, believing that decisions might take longer but that they would be more effective because they were based on consensus. Author 3 challenged both Authors 1 and 2 as to whether the rejection of leadership was more apparent than real.

Perhaps because of the frustration generated by lengthy discussions of process, meetings dwindled to between 12 and 15 attendees, although subgroups formed on the basis of voluntary affiliation went off to do their own thing. Affiliation is a prefigurative organizing practice whereby collective tasks are undertaken on the basis of who wishes to undertake them and who they like to work with rather than direction via bureaucratic rules (McDonald, 2006). Again authors had different interpretations of what was going on. Author 1 felt that the initial energy of the social space project was dissipating but Author 2 shared the view of many of the participants that the process was successfully establishing prefigurative social relations. Subsequent events could be said to vindicate both viewpoints as the social space project was abandoned but then replaced by a more achievable autumn 'festival'. The first 'Discovering Alternative Midtown' festival duly took place in October 2009 and was considered a success by MAC members, leading to further events and activities including three more autumn festivals.

Vignette 2: Prefiguring Space

\begin{abstract}
A festival planning meeting, the 'I' is Author 2, with Jane, John, Mark, Sam and several others.
'They can't open for us any more', I say returning to the group. 'Their manager says we're not spending enough.' We had been meeting in the café's upstairs room for weeks and it was ideal - big, accessible and a regular hangout for the alternative scene. The trouble was a lot of us didn't want to spend the money that made it worthwhile for the café. 'So where do we go then?' responded Jane. We considered
\end{abstract}


people's houses, other cafes, community centres until finally someone suggested a local pub. 'Yep, it's free, big and they will be open anyway' agreed John. 'And it does good beer' called out Mark. A consensus seemed to be emerging until Jane said 'but it's a pub so we can't bring children there and this is meant to be open to everyone'. 'This is why we need a Social Centre' concluded John, 'so we've got somewhere to have meetings like this!'

As detailed above, spaces where assemblies can operate, whether physical or virtual, are an essential element of prefigurative practice. They enable individuals to come together, organize and express their shared identity (Barnard, 2011; Glass, 2012). Workplaces usually offer little scope for being modified by their users in support of individual preferences. They do, however, provide a dedicated place suited to the activities of the organization: no such ready-made spaces existed for the MAC. The creation of compatible organizational spaces therefore formed part of the individuation processes we observed, including, the original aim of creating a social centre.

We used a number of locations for activities. I went to two frequently used pubs, two music venues, three cafes, two alternative shops, a squatted building, and a community centre during my time with the MAC.

From Author 1's Fieldnotes

The selection of these locations was not arbitrary but was governed by whether the subcultural preferences of dress, music, food, and behaviour were welcomed. For those MAC members who were wholly committed to non-commodified forms of life, they also needed to be cheap or preferably free!

Vignette 2 illustrates the tensions that often arose from using spaces only partially amenable to refiguring by the MAC. Those with small children felt excluded by the use of pubs for 
meetings and there was a gendered aspect to the enthusiasm for pubs by young males whose pursuit of conviviality often relied on heavy drinking. A squatted building enabled one subgroup of the MAC to create a temporary social centre that accommodated events for the MAC.

For two and half years, I participated in a wide range of activities with the MAC in the squat, these included social and musical events, event planning, political education and campaigning, communal living, bicycle repair workshops, alternative energy workshops, food production, craft production, exhibitions, music performance, and a reading group amongst other activities.

From Author 2's Fieldnotes

This do-it-yourself, just-get-on-with-it, approach was an important aspect of the MAC's prefigurative ideals and counteracted the tendency for actionless deliberation. However the eventual partial eviction of MAC members from the squat also illustrates the precarity and ephemerality of its results.

The MAC also made extensive use of the immaterial spaces provided by the internet, enabling the coordination and continuation of physical assemblies through social networking sites, on-line magazines, and email lists. One such virtual space was provided by the MacZine:

A bi-monthly black and white zine written \& designed by residents of Midtown and beyond. Whether it's reviews, articles, cartoons, poems, quotes, images, comments, photography, news, diary dates, advice, events, drawings, stories, absolutely anything you want!

Quote from the inside cover of the MacZine, accessed January 2016 
The MacZine was produced in hardcopy for distribution at events but also on-line with a wide range of links to other alternative resources, events, and organizations. The MAC also made use of a Google based website and Facebook, although not without qualms at their corporate ownership.

The group's Google hosted website contains links to all the affiliated groups and times and locations for forthcoming events. There were also organizational resources such as meeting notes and invitations to meetings; requests for information; and discussions regarding values, aims and activities. The group's Facebook page operates more as a discussion forum and noticeboard. They also use Twitter and personal and group blogs.

From Author 1's Fieldnotes

Virtual spaces also enabled ties with groups in other parts of the UK and to global campaigns and activism. The internet extended purely locally based identities to ones that were connected with global activist practices and movements and so enlarged the range of possible activist options out of which individuation projects could be built.

Vignette 3: Conviviality, social bonds and mutual aid

Notes from a festival planning meeting with Author 2, Rob, Lee, Sam, Rowan, Sara and several others.

'Welcome to the first planning meeting for the 'Discovering Alternative Midtown Festival'. Can someone write down who we want to invite?' 'How about Artistic Blocks? Rob and Lee can you run this for us?' 'Sure' said Rob, 'we can also put on a couple of band nights as well, Sam can do sound for you and Pete has a van - you just need to pay his petrol money'. 
The members quickly put together a list of musicians, artists, spoken-word groups, cycling groups, comedians, DJs, organic cosmetic producers, green activists, political speakers, campaigning charities, youth workers, the local LETS organizers and others. Soon a month's worth of events was drawn up from music nights to surrealist 'happenings' that formed the core of the first festival in October 2009. All of these details were then placed on the MAC's Google website.

Conviviality, social bonds and mutual aid are integral to alternative organizing (Parker et al., 2007). The MAC's regular social events facilitated friendship and trust, refined organizational skills and provided opportunities for highly varied forms of self-expression (see vignette 4 below). As with other economically precarious groups (Morris, 2012; Williams, 2006), conviviality provided opportunities for the informal 'trading' of knowledge, skills, favours, labour, spaces, equipment, and ideas, thus supporting the prefigurative practice of self-provisioning. In line with their non-commercial ideals, trading did not wholly rely on monetary exchange, although minimal payments (money for petrol, for example) lubricated non-monetary exchanges. Although, not primarily intended as a means to provide for material necessities, convivial practices did sometimes facilitate paid work (musical performance, for example).

Vignette 4: the creative self: lifestyle art and culture

A Ukrainian folk-punk band is playing and the alternative community stand around drinking in the crowded café. They are a mix of dreadlocked hippy types, some with brightly dyed hair, tattoos and piercings, many men with long hair and beards. Some cluster outside the café smoking roll-ups. Others wear clothes and jewellery they have made themselves or bought from alternative producers in the MAC. At a small stand, Mel is promoting a protest in London the following Saturday. Scott, a local artist, is 
selling some of his swirling avant-garde pictures. Rowan is selling her jewellery. Upstairs an experimental jazz trio play with home-made instruments. Later, Peter takes the stage with two teenagers he has been working with as part of a funded community project and 'spits some bars', giving a hip hop rap that uses their experiences of growing up in Midtown.

An account of a subsequent festival event by Author 2 based on fieldnotes of observations

This vignette illustrates the integration of conviviality, dress, self-provisioning, and artistic self-expression within the MAC. Music was particularly important at MAC events, and reinforced a common youth sub-cultural identity (Glass, 2012; McDonald, 2006; Rimmer, 2010) whilst providing a (small) income for some of its producers. Music production drew on the festival culture, connecting the MAC to a counter-cultural tradition that linked identity projects to a tradition of protest and lifestyle politics reaching back over five decades (McDonald, 2006).

Events such as this enacted a shared desire to create a communal do-it-yourself alternative to the commodified world of entertainment and artistic identities were central to many of the individuation projects of MAC members. The political content of lyrics and poetry also enabled artistic expression to be a political act, the 'speaking-out' that Siegler (2006) argues is a key aspect of individuation.

\section{Vignette 5: Activist Identities}

We don't want to replace one set of bosses and politicians with another, like in the

USSR. We want to abolish government and the control of production by the market.

We want workers and service users to democratically control their own workplaces 
and see ordinary people run the world together without money or authority. This is what we call libertarian communism.

This all sounds very far-fetched but actually it's more realistic than you think. Think about who actually does the important work in society - i.e. people who produce goods and services. We do! We know exactly how to run our workplaces because it's us who do it every day.

\section{Excerpt from the MacZine, January 2012}

All MAC members engaged in some form of activism and for some it was central to their identity projects. The most visible political activists were the self-avowed anarchists whose views the vignette reflects. Anarchists were influential MAC members because they were some of the most active organizers of political campaigns. Despite this influence and the broad consensus around issues of social justice, environmentalism, consumerism, and individual autonomy there were many MAC members reluctant to embrace political labels and who pursued more personalised lifestyle politics. As Chatterton (2010) observes this may reflect an unwillingness to cede personal autonomy to the organizational or ideological discipline associated with political action. Those trying to make a living by selling goods to the wider public also worried that an avowedly political identity might alienate customers. As Rowan stated 'obviously, having a shop, I have to be quite careful with what I do...so I much prefer a softer approach that is sewing little seeds of thought' (interview with Author 1).

Despite these differences, some form of political commitment was an important component of all MAC individuation projects because they gave significance to lives beyond selfgratification or lifestyle. Activism distinguished individualization projects from individuation because of the components of collective action and the devotion of time and energy to political aims. Sometimes this involved risking bodily safety and comfort, as when 
participating in anti-fascist demonstrations or in Occupy ${ }^{\mathbf{i}}$. Bonds of solidarity and trust were strengthened considerably by the need for mutual support and the organization required by such activism.

Vignettes 6 and 7: Individuation in the assembly: speaking out

Vignette 6: Festival planning meeting with Author 2, Adrian, Peter, Mark and several others.

'Sorry, I'm a bit new to all this', says Adrian, a new participant, 'But what are we calling alternative?' A few mutters come from some; they have sat through a fair number of these discussions over the past few weeks. 'No, it's a fair question', says Peter, 'For me, alternative is anything that is non-profit, ethically driven, organized non-hierarchically, working towards improving society, etc... What do others think?' A discussion ensues with Adrian asking more questions. 'We have been here before', sighs Mark, 'How many times do we need to discuss these questions, can't we decide and move on?'

Vignette 7: Festival planning meeting with Author 2, Sam, Clare, Harmony and others

'I've noticed', said Sam, 'that not everyone seems able to join in'. Suddenly the debate about the potential new venues stops and everyone looks at Sam. 'The discussion seems to be dominated by, please don't take offence, but by white men, and you're not letting others do any talking'. 'I agree', states her friend Clare, 'there are a few people who seem to be dominating here'. 'I know what, why don't we have a go-round for everyone that hasn't spoken, so we get to hear their views' suggests Sam. A slightly awkward silence follows and then a few of the group who are yet to speak start offering their views. 'But I don't want to speak, I am just happy listening', states Harmony, a little red in her face, when it comes to her turn. 'We shouldn't have to speak unless we want to'. 
Vignettes 6 and 7 demonstrate the tensions already noted between the autonomy of individuals (including the freedom not to take part or be bound by the decisions of others) and abiding by collective norms that all would contribute to consensus and organizing. It also illustrates that many MAC members were acutely aware of this tension and the tendency of power differentials to establish themselves. MAC members all supported the principle of challenging organizational processes concurring with Maeckelbergh (2009, p.164) that 'when movement members feel excluded or ignored, there is a problem with the process that ought to be addressed'. However, this creates a normative obligation to challenge, 'to be an authentic member is to have the right to shape the group's direction as well as some obligation to do so' (Blee, 2012, p.65). As vignette 7 illustrates such norms may themselves be experienced as oppressive and as constraining autonomy on the one hand or as leading to a frustrating revisiting of old debates as in vignette 6 . The fluid nature of membership meant having to constantly renegotiate the consensus on which a collective alternative identity was founded with potentially disruptive impacts on the effectiveness of the MAC's organization.

The resultant frustrations are common within alternative organizing but are generally accepted as a price worth paying; Polletta's eponymous 'freedom is an endless meeting' (2002). Most MAC members consciously rejected the calculative, efficiency oriented, style of organizing associated with managerial approaches, preferring collective opportunities to develop their identities (illustrated by constant discussion as to the meaning of alternative) and their organizing skills through participation. However, confronting the options for selfhood in assembly could be fraught with contradiction and the threat of collective dissolution.

Vignette 8: Sustaining the self: material provision and work

\section{Excerpt from an interview with Peter.}


'A few years back I did make a decision that I didn't want to be at work full-time, you know, time is more important than money. I like to have a balanced life; it's always something that's been very important to me. I wanted to...I wanted to become a youth worker and work with young people because I knew it would be more informal and we could discuss things that are more liberated and kind of radical and to do with social change. Now I'm a freelance youth worker.'

Individuation projects cannot escape the brute materiality of existence, we all need to eat, but they may influence choices of how material needs are met. MAC members sought to do so in ways congruent with their alternative identities. The pursuit of personal autonomy was widely considered incompatible with the discipline and authoritarianism of the workplace. As illustrated by the interview quote above, the status and consumption associated with career success was also widely rejected. Instead, MAC members desired to spend their time in freely chosen activities and to be as self-sufficient as possible. Different members made different compromises with the world of work with some (generally older participants with children) having full-time jobs, though they often planned to cut down on hours in the future. Others sought to live entirely 'cash-free', with minimal levels of consumption - growing their own food, swapping or making clothes, and squatting for housing. Even here most did some parttime work to get by. Some were lucky enough to get paid for activities that were intrinsically congruent with other aspects of their alternative identities such as Peter above.

Conflicts arose as a result of these compromises. Those with more secure full-time employment, including Author 2, told us that they sometimes felt less authentic than members who were fully immersed in the alternative lifestyle. There was a curious inverted informal hierarchy between less affluent and more affluent MAC members; those with more ideologically pure 'off-grid' lives were sometimes critical of the lack of commitment of more conventional members. 
There seem to be three types of MAC members, the conventionals, with mortgages, full-time jobs and families; the idealists, who rent in shared accommodation and have part-time jobs in socially appropriate employment; and the minimalists, who squat or live in very cheap areas of town, who do occasional work and live on very little money...I always felt they looked down on me because I'm a wage slave and they're living free.

\section{Interview by Author 2 with MAC member}

The shared ideal, however, was to find a way of satisfying material needs that was compatible with an alternative identity i.e. that integrated autonomy, activism, creative selfexpression and an income. This seemed most attainable for creative members who were able to make money playing music or running arts projects. For example, Sara was able to make ends meet (barely) through a UK Arts Council community project, Rowan ran a craft boutique funded by the Prince's Trust. Engagement with the world of business had to be carefully justified by wider non-commercial aims if it was not to give rise to identity conflict and it seemed to be a matter of pride that none of these businesses provided enough income for what most outside the MAC would consider an adequate standard of living.

I have to admit I'm really not looking more than $£ 10,000$ a year for myself. I've never even got $£ 5,000$ in a year, so at the moment that's all I need very comfortably to live off, that's all I'm interested in. I'm not money-orientated.

\section{Quote from interview of Rowan by Author 1}

The desire for autonomy from work sometimes led to a precarious, hand-to-mouth existence. Although this could be valorised as illustrated above as 'living free' it sometimes had less desirable consequences. Peter told us of his frequent bouts of poor mental health due to stress. Rowan told us how exhausting she found doing half a dozen part time jobs whilst 
running her craft shop. It sometimes led to increased dependence on parents and public support also undermining autonomy. One MAC member told us:

The problem is that my boyfriend doesn't work a lot...we're behind on our rent but my parents, bought a house and said "here you go, live in this house", they said "you give us $£ 400$ a month in rent" and I'm behind in what I owe them which pains me greatly because I feel I've let them down.

\section{Interview of Sophie by Author 1}

Additionally, we noted from our interviews that the precarity of work and unstable incomes led to an inability to project their lives into a desired future, often considered essential to a secure sense of identity (Elliott, 2014). Although MAC members made a virtue out of low consumption and self-sufficiency, an individuation founded on the prefigurative ideal of environmental sustainability, the resultant material hardship could undercut both the autonomy and happiness of some MAC members. Their precarity resembled Bauman's (2000) marginalised vagabond identities. Mutual aid to some extent ameliorated these difficulties as did reframing marginality as part of a positive activist identity but, as the quote above illustrates, this appeared only partially successful.

\section{Discussion and Conclusions}

We began our paper by claiming that the study of the everyday prefigurative practices (Kinna, 2005; Maeckelbergh, 2012; Murray, 2010) through which groups such as the MAC pursue individuation projects could enlarge our understanding of the relation between organizing and identity. In our empirical analysis we show how the MAC attempt to create new forms of life and selves in resistance to the norms of individualized society. Individuation stresses that identity work extends beyond the dualistic struggle between 
control and resistance via identification/dis-identification processes that are the common focus in OS (Mumby, 2005). Rather, we have revealed a collective agentic identity project that rejects managerial norms of hierarchy and authority. The MAC pursued Maeckelbergh's (2012, p.207) 'horizontal democracy’ and sought to create Haug’s (2013, p.707) 'free spaces'. The question we turn to in our concluding discussion is the one we began with; can this attempt be considered successful? How and to what extent might individuation based on prefiguration result in more autonomous selves that transcend the commodified limits of the individualized self?

As to the 'how', we have argued that individuation based on prefiguration relies on the maintenance of personal bonds of trust that underpin and are produced through conviviality, mutual aid, activism, self-provisioning, cultural production and shared sub-cultural practices. What distinguishes individuation from mere individualized lifestyle choices is the political consciousness that imbues prefigurative practice with shared values and collective purpose. We have shown that individuation places considerable demands on the skills and commitment of participants in groups such as the MAC and the question remains whether the widely sought individual autonomy was achieved through their collective project and, if so, how? We would tentatively say yes, to some extent. MAC members could plausibly claim not to be cogs in a bureaucratic corporate machine and neither did they measure their self-worth in terms of hierarchical status or success displayed through conspicuous consumption. Conventional identity categories could also be successfully re-appropriated into individuation projects, most strikingly in the case of entrepreneurship, a mainstay of contemporary individualization (du Gay, 2000). MAC members such as Rowan, combined entrepreneurial creativity with political activism and so de-toxified an entrepreneurial identity of its procapitalist connotations. 
In addition, the MAC at least partially overcame the isolation of individualization by forging social bonds supported by interdependence, reciprocity, conviviality and shared values. They restored meaning to work by imbuing it with ethical significance (sustainability, care for others or political change) and by seeing a direct benefit from their own labours through their do-it-yourself, non-commodified self-provisioning. Work could also sometimes be a form of creative self-expression. They consciously attempted to challenge domination, hierarchy and subjection to authority through deliberative democracy in the assembly. Finally, prefigurative practice encouraged a search for happiness in the here and now counteracting a tendency to sacrifice this in the pursuit of future oriented political aims.

We therefore conclude that prefiguration contributed to a degree of autonomy but it also gave rise to many difficulties and contradictions associated with trying to live so much against the grain of dominant social norms. We suggest that the participant ethnographer social movement theorists we draw on above (Chatterton, 2010; and Maeckelbergh, 2012, for example) have a tendency to over-emphasise the positive aspects of individuation projects in the alter-globalization movements. Our sensitivities as organization theorists to the adaptability and persistence of power and hierarchy make us more sceptical. We found that, despite the seemingly consensual nature of alternative organizing, power and domination continue to constrain autonomy. Influential members such as Peter constantly agonised with the contradictions of their putative leadership. Disputes, fragmentation and frustration arose in the MAC because of the difficulty of implementing prefigurative practices in ways congruent with their ideals. That said, MAC members were acutely aware of such problems and took pains to circumvent them through other organizing practices. The social bonds of personal trust and affinity held the MAC together over time, despite tensions, as did reciprocal dependence for self-provision based on mutual aid (clothes swaps, cooperative food production and so on). Again, we conclude that the elements of conviviality, mutual aid, 
political activism, horizontal decision-making, self-provisioning and shared subculture must operate in mutually reinforcing ways in order to sustain individuation. Even so, the question remains as to whether the sheer cost in time, effort and emotional engagement was always worth it for participants.

More positively, debate, disagreement and the resultant spinning off of new groups and projects provided opportunities for individuals to modify and experiment with their personal and collective identities. Despite what might be seen as fragmentation, the MAC did sustain collective projects. The festivals did happen and the 'unofficial' social space was created and endured for several years. Thus the conflict sometimes engendered by prefigurative practice may be viewed as both potentially productive and destructive of individuation projects.

Is individuation via prefigurative practice an option for a wider constituency other than committed activists? Many MAC members embraced a marginal 'off-grid' identity as part of their individuation that may not appeal to wider numbers. Whilst conventional work and consumption require a large degree of conformity to the norms of individualization, they also still provide a degree of meaning, material comfort and stability for many individuals, although arguably in declining numbers. It is easy for those of us caught up in career pressures, long working hours, and financial commitments to romanticise the seemingly free, hedonistic, irresponsible and leisured existence of these contemporary 'drop-outs'. In reality living 'off-grid' involves both material and psychic precariousness. Evictions, lack of money for basic needs such as food, clothes and transport, physical discomfort and poor health, political disappointment, depression, unstable family and personal relationships - all were common features of MAC members' lives. Such experiences are more reminiscent of the precarious working poor than associated with autonomous selfhood (Fleming, 2015; 
Standing, 2014) and undermined more positive aspects of their individuation projects.

Questions thus remain as to what extent the anxious, insecure and fragmented individual portrayed by Beck and Beck-Gernsheim (2002), Bauman (2000) and Sennett (1998) may be transcended by the individuation project of alternative groups. As with all identity projects there may be a large element of making a biographical virtue out of a structural necessity, imbuing economic precariousness with agentic individuation. Indeed only very few MAC members themselves were able to sustain a complete commitment to these practices. Most compromised with paid work and conventional ways of life to a greater or lesser extent, a tendency that increased with age.

\section{Final Thoughts}

In this paper we contribute to the understanding of identity within organization studies by developing the concept of individuation pursued through prefigurative practices. This concept reframes the relation between organizing and identity. Specifically we see that identity may be undertaken as an active collective re-appropriation of organizing as a means of achieving more autonomous selves. Our study has revealed that prefiguration does enable some gains in terms of autonomy as defined as freedom from the commodified competitive self of the individualization thesis. Such gains are only possible when identity as consumption or competition is consciously challenged through individuation as a political project. Moreover practices associated with creating spaces for assembly, conviviality, maintenance of personal bonds, mutual aid, self-provision, creativity and sub-cultural markers are all required to become mutually reinforcing through political purpose and shared values in order to sustain individuation. Further study might investigate the potential of other forms of individuation to colonise more mainstream forms of organization. Likewise, the significant social and 
technological changes we allude to in our introduction may create both the necessity and opportunity for the extension of the prefigurative practices we identify to larger, less marginal groups. This provides a potentially rich and significant seam of future work for organization scholars wishing to understand how identity is changing in the contemporary world. A new organizational studies that theorises this emerging relationship between identity, selforganization and politics is thus required and the paper has been an attempt to contribute to this project. 


\section{References}

Ahrne, G., \& Brunsson, N. (2011). Organization outside organizations: the significance of partial organization. Organization, 18(1), 83-104.

Alvesson, M. (2003). Methodology for Close-Up Studies - struggling with closeness and closure. Higher Education, 46, 167-193.

Alvesson, M., Ashcraft, K. L., \& Thomas, R. (2008). Identity Matters: Reflections on the construction of identity scholarship in organization studies. Organization, 15(1), 5-28.

Alvesson, M., \& Skoldberg, K. (2000). Reflexive Methodology. London: Sage.

Alvesson, M., \& Willmott, H. (2002). Identity Regulation as Organizational Control: Producing the appropriate individual. Journal of Management Studies, 39(5), 619644.

Araujo, K., \& Martuccelli, D. (2014). Beyond institutional individualism: agentic individualism and the individuation process in Chilean society. Current Sociology, 62(1), 24-40.

Atkinson, W. (2008). Not All That was Solid Has Melted Into Air (Or Liquid): A critique of Bauman on individualization and class in liquid modernity'. The Sociological Review, 56(1), 1-17.

Atkinson, W. (2010). Phenomenological Additions to the Bourdieusian Toolbox: Two Problems for Bourdieu, Two Solutions from Schutz. Sociological Theory, 28(1), 1-19.

Barnard, A. V. (2011). 'Waving the Banana' at Capitalism: Political theatre and social movement strategy among New York's 'freegan' dumpster divers. Ethnography, 12(4), 419-444.

Barratt, E. (2003). Foucault, HRM and the Ethos of the Critical Management Scholar. Journal of Management Studies, 40(5), 1069-1087.

Barter, C., \& Renold, E. (2000). 'I Wanna Tell You A Story': The use of vignettes in qualitative research. International Journal of Social Science Methodology, 3(4), 307323.

Bauman, Z. (2000). Liquid modernity. Cambridge :: Polity Press ;.

Beck, U. (1997). The Reinvention of Politics: Rethinking modernity in the global social order. Cambridge: Polity.

Beck, U., \& Beck-Gernsheim, E. (2002). Individualization: Institutionalized Individualism and its Social and Political Consequences. London: Sage.

Beech, N. (2008). On the Nature of Dialogic Identity Work. Organization, 15(1), 51-74.

Bieler, A. (2011). Labour, New Social Movements and the Resistance to Neoliberal Restructuring in Europe. New Political Economy, 16(2), 163-183.

Blee, K. M. (2012). Democracy in the Making: How activist groups form. Oxford: Oxford University Press.

Böhm, S., Dinerstein, A. C., \& Spicer, A. (2010). (Im)possibilities of Autonomy: social movements in and beyond capital, the state and development. Social Movement Studies, 9(1), 17-32.

Boucher, H. C., \& Maslach, C. (2009). Culture and Individuation: the role of norms and selfconstruals. The Journal of Social Psychology, 149(6), 677-693.

Brunwick, T., \& Coghlan, D. (2007). In Defence of Being "Native": The case for insider academic research. Organizational Research Methods, 10(1), 59-74.

Castells, M. (2012). Networks of Outrage and Hope. Cambridge: Polity.

Castells, M., Caraça, J., \& Cardoso, G. (Eds.). (2012). Aftermath: The cultures of the economic crisis. Oxford: Oxford University Press.

Chatterton, P. (2010). So What Does It Mean to be Anti-capitalist? Conversations with Activists from Urban Social Centres. Urban Studies, 47(6), 1205-1224. 
Chatterton, P., \& Pickerill, J. (2010). Everyday activism and transitions towards postcapitalist worlds. Transactions of the Institute of British Geographers, 35(4), 475490.

Clemens, E., \& Minkoff, D. (2004). Beyond the Iron Law: Rethinking the place of organizations in social movement research. In D. Snow, S. Soule, \& H. Kriesi (Eds.), The Blackwell Companion to Social Movements (pp. 155-170). Malden, MA: Blackwell.

Collinson, D. (2003). Identities and Insecurities: Selves at work. Organization, 10(3), 527 547.

Costas, J., \& Fleming, P. (2009). Beyond Dis-identification: A discursive approach to selfalienation in contemporary organizations. Human Relations, 62(3), 353-378.

Cunliffe, A. L. (2010). Retelling Tales of the Field: In search of organizational ethnography 20 years on. Organizational Research Methods, 13(2), 224-239.

Davies, A. D. (2012). Assemblage and Social Movements: Tibet support groups and the spatialities of political organisation. Transactions of the Institute of British Geographers, 37, 273-286.

Diefenbach, T., \& Sillince, J. A. A. (2011). Formal and informal hierarchy in different types of organization. Organization Studies, 32(11), 1515-1537.

du Gay, P. (1996). Consumption and Identity at Work. London: Sage.

du Gay, P. (2000). Enterprise and its Futures: A Response to Fournier and Grey. Organization, 7(1), 165 - 183.

du Gay, P., Salaman, G., \& Rees, B. (1996). The Conduct of Management and the Management of Conduct: Contemporary managerial discourse and the constitution of the "competent manager". Journal of Management Studies, 33(3), 263-282.

Elliott, A. (2014). Concepts of the Self (3rd ed.). Cambridge: Polity.

Featherstone, D. (2008). Resistance, Space and Political Identities: The making of counterglobal networks. Oxford: Blackwell.

Fenton, N., \& Barassi, V. (2011). Alternative Media and Social Networking Sites: The politics of individuation and political participation. The Communication Review, 14(3), 179-196.

Fleming, P. (2015). The Mythology of Work: How capitalism persists despite itself. London: Pluto Press.

Fominaya, C. F. (2010). Creating Cohesion from Diversity: The Challenge of Collective Identity Formation in the Global Justice Movement. Sociological Inquiry, 80(3), 377404.

Fortune, D., \& Mair, H. (2011). Notes from the Sports Club: Confessional tales of two researchers. Journal of Contemporary Ethnography, 40(4), 457-484.

Fournier, V. (2006). Breaking from the Weight of the Eternal Present: Teaching Organizational Difference. Management Learning, 37(3), 295 - 311.

Freeman, J. (2013). The Tyranny of Structurelessness. Women's Studies Quarterly, 41(3\&4), 231-246.

Gautney, H. (2009). Between Anarchism and Autonomist Marxism. Working USA: The journal of labour and society, 12, 467-487.

Gibson-Graham, J. K. (2006). The End of Capitalism (as we knew it). Minneapolis: University of Minnesota Press.

Gibson-Graham, J. K., Cameron, J., \& Healey, S. (2013). Take back the economy: an ethical guide for transforming our communities. Minneapolis: University of Minnesota Press.

Giddens, A. (1991). Modernity and Self Identity. Cambridge: Polity Press.

Glass, P. G. (2012). Doing Scene: Identity, space and the international accomplishment of youth culture. Journal of Contemporary Ethnography, 41(6), 695-716. 
Hardt, M., \& Negri, A. (2000). Empire. Cambridge, Mass.: Harvard University Press.

Hardt, M., \& Negri, A. (2004). Multitude: War and democracy in the age of empire. New York: Penguin.

Haug, C. (2013). Organizing Spaces: Meeting Arenas as a Social Movement Infrastructure between Organization, Network and Institution. Organization Studies, 34(5-6), 705732.

Heras-Saizarbitoria, I. (2014). The Ties That Bind? Exploring the basic principles of workerowned organizations in practice. Organization, 21(5), 645-665.

Hodgson, D. E. (2000). Discourse, Discipline and the Subject. Aldershot: Ashgate.

Honneth, A. (2004). Organized self-realization: some paradoxes of individualization. European Journal of Social Theory, 7(4), 463-478.

Humphreys, M. (2005). Getting Personal: Reflexivity in autoethnographic vignettes. Qualitative Inquiry, 11(6), 840-860.

Humphreys, M., Brown, A., \& Hatch, M. J. (2003). Is Ethnography Jazz? Organization, $10(1), 5-31$.

Imas, M., J., \& Weston, A. (2012). 'From Harare to Rio de Janeiro: Kikiye-Favela organization of the excluded. Organization, 19(2), 205-227.

Imas, M., J., Wilson, N., \& Weston, A. (2012). Barefoot Entrepreneurs. Organization, 19(5), 563-585.

Karra, N., \& Phillips, N. (2008). Researching "Back Home": International management research as auto-ethnography. Organizational Research Methods, 11(3), 541-561.

Kinna, R. (2005). Anarchism. Oxford: Oneworld Publications.

Kokkinidis, G. (2011). In Search of Workplace Democracy. International Journal of Sociology and Social Policy, 32(3/4), 233-256.

Kokkinidis, G. (2014). Spaces of Possibilities: workers' self-management in Greece. Organization, 1-25. doi:10.1177/1350508414521098

Maeckelbergh, M. (2009). The Will of the Many: how the alterglobalisation movement is changing the face of democracy. London: Pluto Press.

Maeckelbergh, M. (2011a). Doing is Believing: prefiguration as strategic practice in the alterglobalization movement. Social Movement Studies, 10(1), 1-20.

Maeckelbergh, M. (2011b). The Road to Democracy: the political legacy of "1968". IRSH, 56, 301-332.

Maeckelbergh, M. (2012). Horizontal Democracy Now: From Alterglobalization to Occupation. Interface, 4(1), 207-234.

Marx, K. (1873/1973). Grundrisse: foundations of the critique of political economy. London: Allen Lane.

McAdam, D., McCarthy, J. D., \& Zald, M., N. (1996). Comparative Perspectives on Social Movements: Political opportunities, mobilizing structures and cultural framings. New York: Cambridge University Press.

McCabe, D. (2008). Who's Afraid of Enterprise?: Producing and repressing the enterprise self in a UK bank. Organization, 15(3), 371-387.

McDonald, K. (2006). Global Movements: Action and culture. Malden, MA: Blackwell.

Melucci, A. (1989). Nomads of the Present: Social movements and individual needs in contemporary society. Philadelphia: Temple University Press.

Moore, R., \& Roberts, M. (2009). Do-It-Yourself Mobilization: Punk and social movements. Mobilization, 14(3), 273-291.

Morris, J. (2012). Beyond Coping? Alternatives to Consumption within a Social Network of Russian Workers. Ethnography, 14(1), 85-103.

Mumby, D. K. (2005). Theorizing Resistance in Organization Studies: A dialectical approach. Management Communication Quarterly, 19(1), 19-44. 
Murray, D. (2010). Democratic Insurrection: Constructing the common in global resistance. Millenium: Journal of International Studies, 39(2), 461-482.

Owen, H. (2008). Open Space Technology: A user's guide. San Francisco: Berrett-Koehler.

Parker, M. (2002). 'The Romance of Lonely Dissent': Intellectuals, Professionals and the McUniversity. In M. Dent \& S. Whitehead (Eds.), Managing Professional Identities (pp. 138-156). London: Routledge.

Parker, M. (2012). Super Flat: Hierarchy, culture and dimensions of organizing. In T. Diefenbach \& R. Todnem (Eds.), Reinventing Hierarchy and Bureacracy - from the Bureau to Network Organizations (Research in the sociology of organizations) (Vol. 35, pp. 229-247).

Parker, M., Cheney, G., Fournier, V., \& Land, C. (Eds.). (2014). The Routledge Companion to Alternative Organization. Abingdon: Routledge.

Parker, M., Fournier, V., \& Reedy, P. (2007). The Dictionary of Alternatives. London: Zed Books.

Pickard, V. W. (2006). United Yet Autonomous: Indymedia and the struggle to sustain a radical democratic network. Media, Culture and Society, 28(3), 315-336.

Polletta, F. (2002). Freedom is an Endless Meeting: Democracy in American Social Movements. Chicago: University of Chicago Press.

Putnam, R. D. (2000). Bowling Alone: The collapse and revival of American community. New York: Simon \& Schuster.

Read, J. (2011). The Production of Subjectivity: from transindividuality to the commons. New Formations, 70(19), 113-131.

Reedy, P., \& Learmonth, M. (2009). Other Possibilities: The contribution to management education of alternative organizations. Management Learning, 40(3), 241-258.

Rimmer, M. (2010). Listening to the Monkey: Class, youth and the formation of a musical habitus. Ethnography, 11(2), 255-285.

Rose, N. (2000). Identity, Genealogy, History. In P. Du Gay, J. Evans, \& P. Redman (Eds.), Identity: A reader (pp. 311-324). London: Sage.

Rozuel, C., \& Kakabadse, N. (2010). Ethics, spirituality and self: managerial perspective and leadership implications. Business Ethics: A European Review, 19(4), 423-436.

Saunders, C. (2008). Double-edged Swords? Collective identity and solidarity in the environment movement. The British Journal of Sociology, 59(2), 227-253.

Sennett, R. (1998). The Corrosion of Character. New York \& London: WW Norton.

Soule, S., A. (2012). Social Movements and Markets, Industries and Firms. Organization Studies, 33(12), 1715-1733.

Spicer, A., \& Böhm, S. (2007). Moving Management: Theorizing struggles against the hegemony of management. Organization Studies, 28(11), 1667-1698.

Springer, S. (2012). Anarchism! What Geography Still Ought to Be. Antipode, 44(5), 16051624.

Standing, G. (2014). The Precariat: The new dangerous class. London: Bloomsbury.

Stiegler, B. (2006). The Disaffected Individual in the Process of Psychic and Collective Disindividuation. Retrieved from http://arsindustrialis.org/disaffected-individualprocess-psychic-and-collective-disindividuation

Sutherland, N., Land, C., \& Böhm, S. (2013). Anti-leaders(hip) in social movement organizations: the case of autonomous grassroots groups. Organization, O(0), 1-23.

Van Manaan, J. (2010). A Song for my Supper: More tales of the field. Organizational Research Methods, 13(2), 240-255.

Wall, M. A. (2007). Social Movements and Email: Expressions of online identity in the globalization protests. New Media \& Society, 9(2), 258-277. 
Watson, T. (2012). Making Organizational Ethnography. Journal of Organizational Ethnography, 1(1), 15-22.

Whittle, A., Mueller, F., \& Mangan, A. (2009). Storytelling and 'Character': Victims, Villains and Heroes in a Case of Technological Change. Organization, 16(3), 425-442.

Williams, C. C. (2006). The Hidden Enterprise Culture: Entrepreneurship in the underground economy. Cheltenham: Edward Elgar.

Willmott, H. (2008). Critical Management and Global Justice. Organization, 15(6), 927-931.

Ybema, S., Keenoy, T., Oswick, C., Beverungen, A., Ellis, N., \& Sabelis, I. (2009).

Articulating Identities. Human Relations, 62(3), 299-322.

Ybema, S., Yanow, D., Vels, H., \& Kamsteeg, F. H. (2009). Organizational Ethnography: Studying the complexities of everyday life. London: Sage.

Zald, M. N., \& Lounsbury, M. (2010). The Wizards of Oz: Towards an Institutional Approach to Elites, Expertise and Command Posts. Organization Studies, 31(7), 963 996.

\footnotetext{
'An interlinked series of protest occupations of public spaces in a number of cities across the world by a coalition of anti-capitalist social movements following in the wake of the 2008 financial crash.
} 